\title{
Review of selected recent research on US seismic design and retrofit strategies for steel structures
}

\author{
Michel Bruneau', Michael Engelhardt ${ }^{2}$, Andre Filiatrault ${ }^{3}, \mathrm{~S} C$ Goel $^{4}$, Ahmad Itani $^{5}$, Jerome Hajjar ${ }^{6}$, \\ Roberto Leon ${ }^{7}$, James Ricles ${ }^{8}$, Bozidar Stojadinovic ${ }^{9}$ and Chia-Ming Uang ${ }^{10}$ \\ ${ }^{\prime}$ University at Buffalo, Buffalo, NY, USA \\ 2 University of Texas Austin, Department of Civil Engineering, Austin, TX, USA \\ 3 University at Buffalo, Buffalo, NY, USA \\ ${ }^{4}$ University of Michigan, Ann Arbor, MI, USA \\ ${ }^{5}$ University of Nevada Reno, Reno, NV, USA \\ ${ }^{6}$ University of Minnesota, Minneapolis, MN, USA \\ ${ }^{7}$ Georgia Institute of Technology, Atlanta, GA, USA \\ ${ }^{8}$ Lehigh University, Bethlehem, PA, USA \\ ${ }^{9}$ University of California Berkeley, Berkeley, CA, USA \\ ${ }^{10}$ University of California San Diego, La Jolla, CA, USA
}

\begin{abstract}
Summary
This paper provides a brief review of selected recent work on the development of solutions for the seismic design and retrofit of steel structures by various members of the US research community. In particular, this paper focuses on research on retrofit of beam-to-column moment
\end{abstract}

connections, frame modifications at beams' midspan, self-centering systems, zipper frames, buckling-restrained braced frames, steel plate shear walls, plastic and rotation limits for buildings, and shear links and truss piers for bridges.

Key words: seismic; design; retrofit; ductile details; inelastic response; innovative systems

Prog. Struct. Engng Mater. 2005; 7:103-114

Published online 29 April 2005 in Wiley InterScience (www.interscience.wiley.com). DOI: 10.1002/pse.192

\section{Introduction}

Although much effort has been invested in recent years in the US to seismically retrofit buildings with unreinforced masonry walls and reinforced concrete frames, steel buildings and bridges have also received significant attention. In buildings with steel frames, this interest in seismic design and retrofit stems from the realization, following the 1994 Northridge earthquake, that the welded beam-to-column connections in moment-resisting frames were likely to fail in a brittle manner, prior the development of significant inelastic response, thus negating the design intent and possibly causing safety hazards. A second impetus was provided by passage of the California Senate Bill 1953 that mandates that all health care facilities providing acute care services be retrofitted to a life-safety performance level by 2008, and a full-serviceability level by 2030. For bridges, important seismic evaluation and retrofit of major crossings have occurred since a span of the San Francisco-Oakland Bay bridge collapsed during the 1989 Loma Prieta earthquake. Large steel truss bridges were evaluated and in some cases retrofitted in most states where these important lifelines exist, including California, Washington, Oregon, New York, and the Mid-West States. Much of that prior work has been reported previously, and detailed overviews of these major retrofit projects would best be the domain of a textbook.

However, it is important that recent research has expanded the variety and versatility of the tools available in the structural engineer's toolbox to meet seismic performance objectives. As such, this brief paper provides an overview of how this research is expanding the available options for the seismic design and retrofit of steel building and bridges in the US, by reporting on some selected recent research projects by US researchers and by providing references to guide the reader for further studies. 


\section{Recent US research for retrofit of buildings}

\section{Retrofit of Beam-to-Column Moment ConNeCtions}

The damage to welded beam-to-column connections in steel moment resisting frames following the January 1994 Northridge earthquake has been well documented elsewhere[1]. Brittle fractures originated in the beam flange groove welds and often propagated to rupture beam flanges (welds or basemetal) or column flanges. Given that this connection detail has been widely used across the US in building frames to resist wind and seismic forces, the poor performance of these moment-resisting connections during the Northridge earthquake raises concerns, and new seismic design or retrofit of connections in existing steel buildings may be desirable to avoid similar failures in future earthquakes.

A co-operative effort by the National Institute of Standards and Technology (NIST), the American Institute of Steel Construction (AISC), the University of California at San Diego, the University of Texas at Austin, and Lehigh University, examined three techniques for retrofit of existing steel moment connections: (i) reduced beam section (RBS) at the bottom flange of the beam; (ii) welded haunch at the bottom flange of the beam, and; (iii) bolted brackets.

These techniques were experimentally assessed using full-scale moment connection specimens (with and without a composite concrete floor slab). PreNorthridge welded flange-bolted web connections were built, using low-toughness weld metal at the beam flange groove welds to replicate pre-Northridge connections details and materials, then retrofitted using the above techniques. Analytical research on the same connections complemented this work, and design models and guidelines were recommended.
A target plastic rotation capacity of 0.02 rad was selected. The results of this program can be summarized as follows:

- the use of a bottom flange RBS or a bottom flangebolted bracket, with the existing low-toughness beam flange groove welds left in place, provided no significant improvement in performance as compared to the pre-Northridge welded flangebolted web connection;

- the use of a bottom flange RBS, combined with the replacement of top and bottom beam flange groove welds with high-toughness weld metal, provided plastic rotations of the order of $0.02-0.025 \mathrm{rad}$. The presence of a composite slab had little effect on the performance of this retrofit technique;

- the addition of a welded bottom haunch, with the existing low-toughness beam flange groove welds left in place, resulted in significantly improved connection performance. The performance of this retrofit technique was significantly influenced by the presence or absence of a composite concrete floor slab. In the absence of a concrete floor slab, the welded bottom haunch specimens developed plastic rotations of $0.015-0.025 \mathrm{rad}$. When a concrete floor slab was present, the specimens developed plastic rotations in excess of $0.03 \mathrm{rad}$. Consequently, the composite concrete floor slab provided a significant beneficial effect for the bottom welded haunch connection;

- the use of bolted brackets at the top and bottom flanges provided plastic rotations in excess of $0.03 \mathrm{rad}$.

Note that, for seismic retrofit, Uang et al.[2] and $\mathrm{Yu}$ et al.[3] showed that the welded haunch scheme (Fig. 1) eliminates the need to modify the existing groove weld of the top flange. They also demonstrated that conventional beam theory cannot provide a reliable

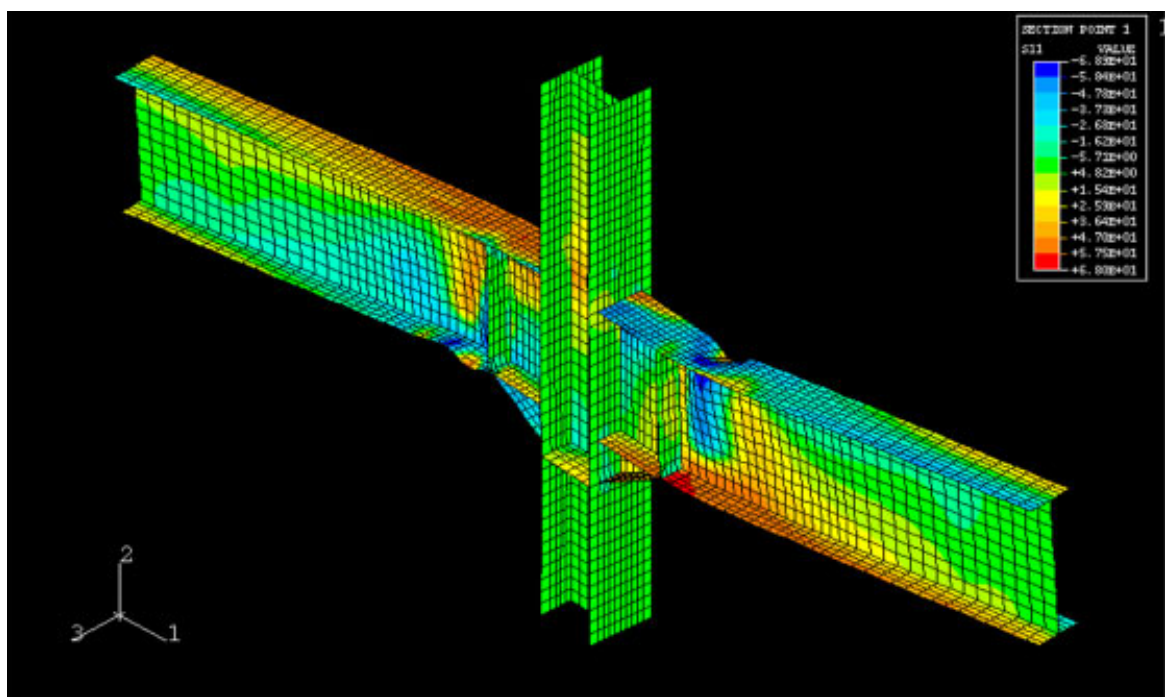

Fig. I Model of welded haunched retrofit scheme 
prediction of the flexural stresses in the groove welded joint, and proposed a simplified model that considers the interaction of forces and deformation compatibility between the beam and the haunch, that can in turn be used to develop a step-by-step design procedure.

The AISC Design Guide No. 12, Modification of Existing Welded Steel Moment Frame Connections for Seismic Resistance[4] was produced as a result of this research. Civjan et al. also provide information on this research.[5-7]

As part of a broader research effort to improve knowledge on the behavior of moment connections recommended by FEMA-350, Hajjar et al.[8] investigated the adequacy of the design provisions for column stiffening, including both continuity and doubler plate detailing, for non-seismic and seismic design conditions, and proposed alternative column stiffener details. Component testing included monotonically loaded pull-plate experiments[9], cyclically loaded beam-to-column connections[10], and parametric finite element analyses[11]. They concluded [8] that the 'AISC non-seismic design provisions for local web yielding and local flange bending are reasonable and slightly conservative in calculating the need for column stiffening'. They also provided new design equations for the limit states of local flange bending, local web yielding, and panel zone shear in fully restrained moment connections, and presented doubler plate details that avoid welding to the column $k$-line, and that performed satisfactorily under monotonic loading (Fig. 2)[8] and cyclic loading[10,12].
In other work, Tort \& Hajjar[13] reviewed the seismic performance of rectangular concrete-filled steel tubes (RCFT) columns and beam-columns on the basis of how damage progressed through testing, both for monotonically and cyclically loaded specimens, for tests conducted worldwide. Deformation-based and energy-based damage functions were used to quantify this data. This database of information provides a platform from which reliability-based performancebased design provisions can be developed for RCFT.

\section{FrAME MOdificATIONS AT BEAM MID-SPAN}

Leelataviwat et al.[14] focused on retrofitting momentresisting frames by introducing a ductile 'fuse' element in shear at mid-span of beams instead of modifying the beam-to-column connections (Fig. 3). This alternative scheme moves the plastic deformation demands away from these critical regions, while ensuring that the existing non-ductile moment frames develop a ductile mechanism. This is achieved by creating a specially braced rectangular opening in the web of each girder near the mid-span. Experimental and analytical research demonstrated the effectiveness of the strategy. The proposed scheme is applicable to both upgrading of existing frames, as well as new construction.

\section{Self-Centering systems}

Christopoulos et al.[15,16] and Collins \& Filiatrault[17] proposed the design of self-centering structural systems as economical alternatives to special moment resisting frame used in the US for the seismic retrofit

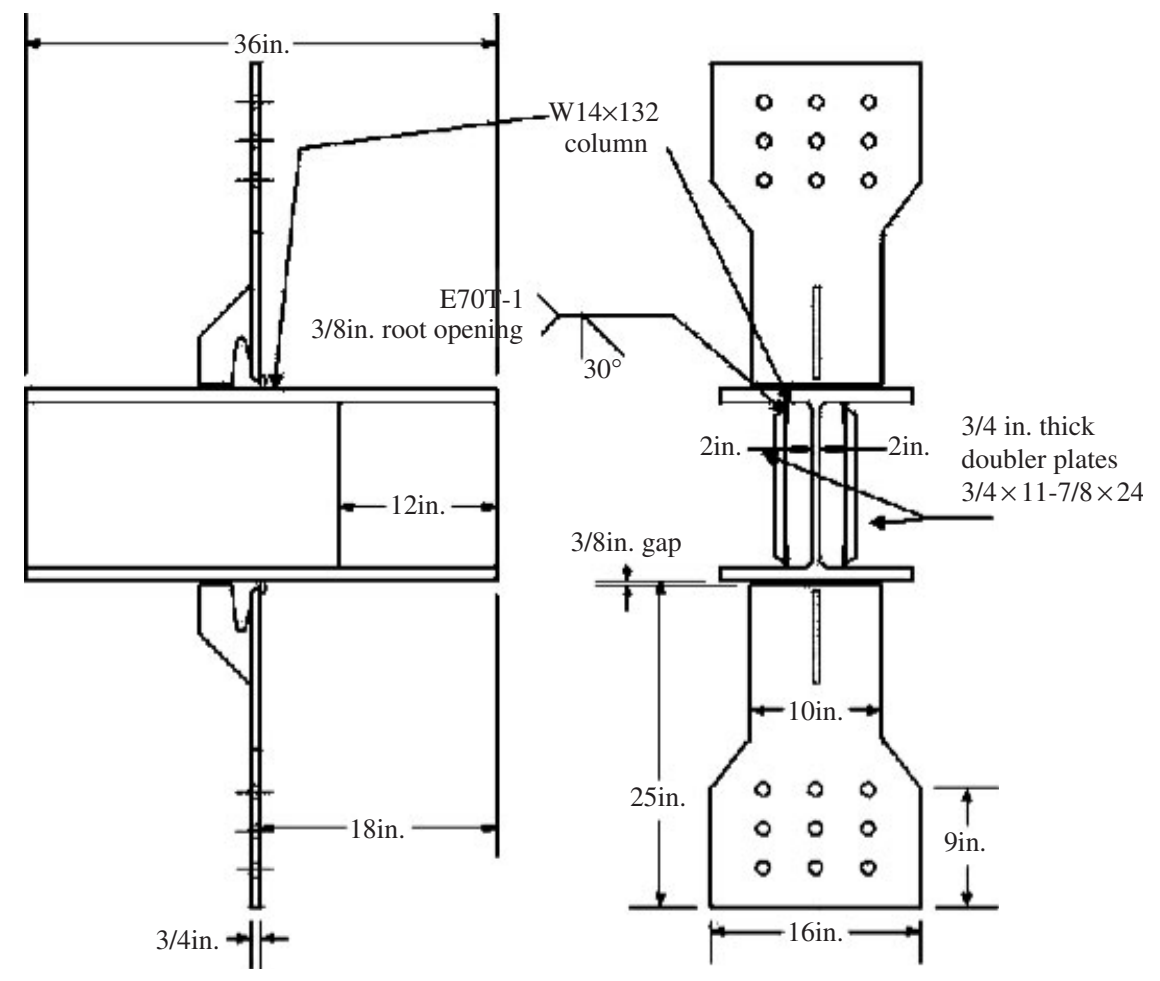

Fig. 2 Detail of doubler plates welded to the column flange away from web[8] 

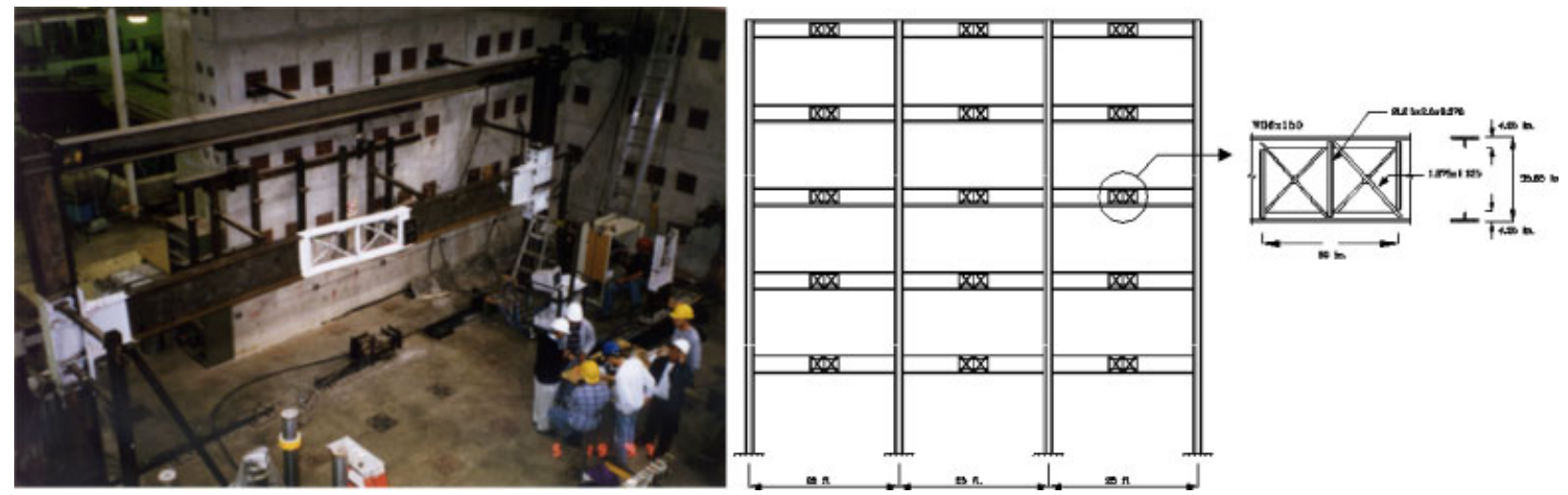

Fig. 3 Frame modified with mid-span truss opening[14]

of steel framed structures. These innovative structural systems:

- Incorporate the nonlinear characteristics of yielding structures and, thereby, limit the induced seismic forces and provide additional damping characteristics

- Encompass self-centering properties allowing the structural system to nearly return to its original position after an earthquake

- Reduce or eliminate cumulative damage to the main structural elements.

The proposed design (Fig. 4) is a post-tensioned Energy Dissipating (PTED) steel frame[15,16]. Highstrength bars or tendons located at mid-depth of the beam provide the post-tension at each floor. Four symmetrically placed energy-dissipating (ED) bars threaded into couplers welded at various locations provide energy dissipation under cyclic loading. Confining steel sleeves are used to prevent the ED bars from buckling during cyclic inelastic loading. Holes in the column flanges accommodate the PT and ED bars. A corresponding hysteretic model is shown in Fig. 5.

Researchers at Lehigh University[18-21] also independently developed a post-tensioned moment connection for use in seismic resistant steel moment frames and composite moment-resisting frames with concrete-filled steel tube columns and wide flange steel beams. Their particular connection relies on high-strength steel strands post-tensioned after bolted top-and-seat angles are installed (Fig. 6). Inelastic deformation of (replaceable) top-and-seat angles provides energy dissipation in this case. The vertical shear is redundantly supported by both the angles and the friction between the beam and the column. The system is also redundant in that it can continue to perform satisfactorily if failure of one or more strands occurs. Time-history analysis[20] showed that multistorey special moment-resisting frames with posttensioned moment connections perform well during strong earthquakes, maintaining their self-centering capability and having no residual drift following the earthquake.

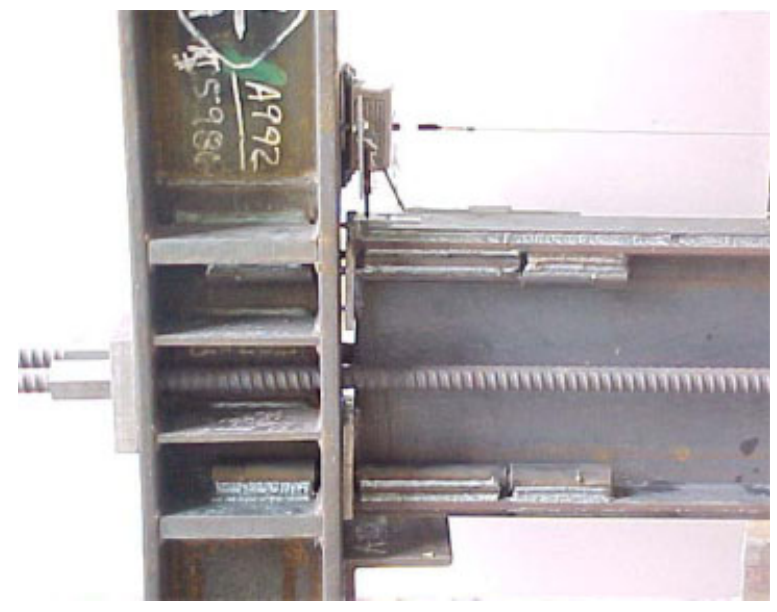

Fig. 4 PTED system[15]

In both studies, cyclic quasi-static testing showed that PT steel connections specimens can exhibit stable self-centering hysteretic behaviour when beam local buckling and strand yielding do not occur. Garlock et al. $[18,19]$ indicated that greater strength and ductility was achieved in connections with more strands. On the basis of time-history analyses of design examples, both groups concluded that frames with PT steel connections can provide adequate seismic performance, including strength, stiffness, 'ductility' and drift capacity, when subjected to earthquake loading.

\section{ZiPPER Frames}

Leon \& Yang[22] developed a simplified design procedure for suspended zipper frames. Such frames are built from inverted V-braced frames by adding zipper columns (i.e. vertical members connecting to the intersection points of the braces above the first floor), an elastic hat truss at the top story, and a capacity design procedure that establishes a clear hierarchy of yielding (Fig. 7). This is done to distribute uniformly along the frame height the unbalanced vertical force generated when braces buckle. 

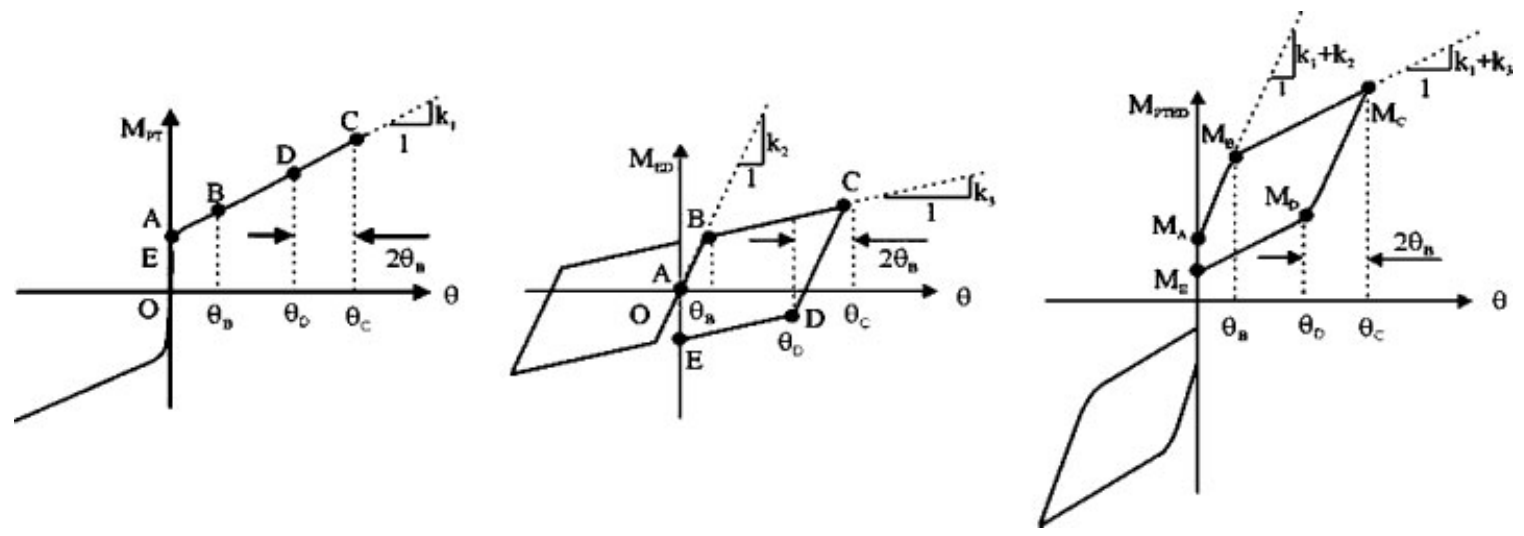

Fig. 5 Hysteretic model for PTED system[15]

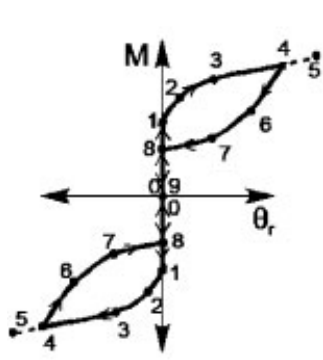

(a)

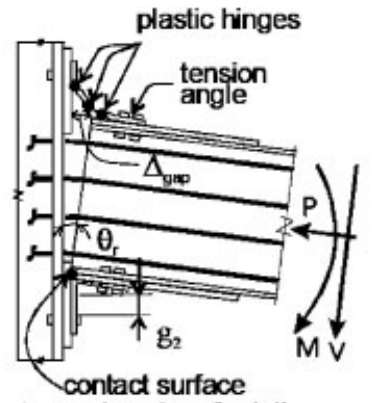

(b) and center of rotation

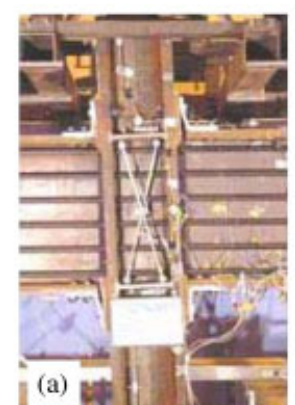

(a)

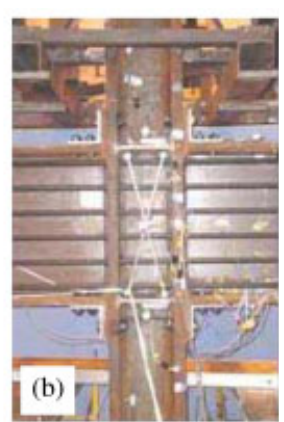

Fig. 6 Post-tension moment connection with top and bottom seat angles[19]
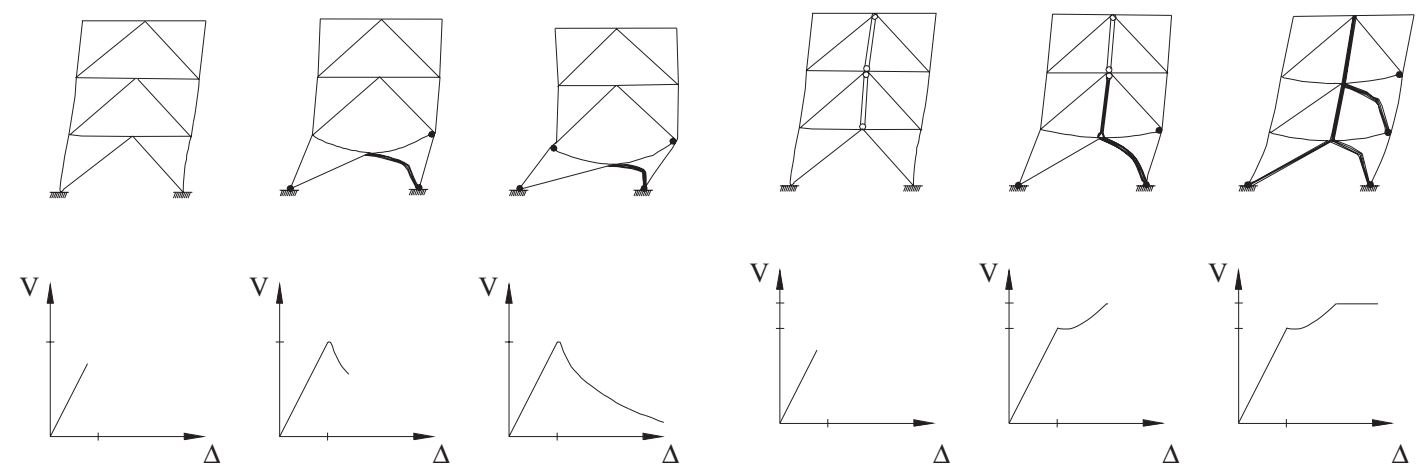

Fig. 7 Push-over curves for inverted V-braced frames and suspended zipper frames

Zipper columns, first proposed by Khatib et al.[23], tie all brace-to-beam intersection points together, and are intended to force all compression braces in a braced bay to buckle simultaneously, and thus better distribute energy dissipation over the height of the building. However, concerns exist that instability and collapse could develop once the full-height zipper mechanism forms, because of the frame's lower lateral capacity beyond that point[24]. Moreover, a capacity design approach for zipper frames requires assumptions on what should be the desirable plastic collapse mechanism.

Leon \& Yang proposed overcoming the disadvantages of a full-height zipper mechanism by introducing a suspension system - suspended zipper frame. In a suspended zipper frame, the top storey braces are designed to remain elastic; all other compression braces are designed to buckle. The suspended zipper struts are designed to yield in tension. Overall, lighter beams and zipper struts are obtained by this design philosophy. This also makes a capacity design procedure possible. Leon \& Yang showed that their proposed design strategy results in ductile suspended zipper frames, with superior seismic performance and strength compared with ordinary zipper frames.

The analytical studies have shown that the behaviour of zipper frames is quite sensitive to the relative sizes of the main structural members. Small changes in member sizes can lead to different failure modes and yielding patterns in both the push-over and nonlinear time-history analyses. Both push-over and nonlinear time-history analyses have shown that zipper frames can sustain drifts in the $3-4 \%$ range 
without significant deterioration of strength. However, the energy dissipation of the system is highly dependent on the model for the braces. The models used vary primarily in the deformation and capacity at the onset of buckling, the magnitude of the deterioration after buckling, the cyclic strengthdeformation rules, and the inclusion of fracture in the analysis. The results for buckling have also been very sensitive to assumption about initial imperfections. Small changes in this imperfection result in large changes in behavior. A suitable value for this imperfection that minimizes differences between models appears to be in the range of $L / 1000$ to $L / 22500$.

A distributed experiment is underway to validate the suspended zipper frame concept. In that project, shake-table tests will be conducted at the University at Buffalo on a 1/3-scale specimen to verify analytical models, frame behavior, and to establish displacement and storey force response histories. These displacement histories will then be used by researchers at the University of California, Berkeley, and the University of Colorado, Boulder, in fast hybrid pseudo-dynamic tests on subassemblages of the first and second floor of the test structure, and by researchers at Georgia Tech will use displacements and force histories as input for further quasi-static tests on scale melds and full-scale frames.

\section{BUCKLING-RESTRAINED BRACED FRAMES}

Buckling-restrained braced (BRB) frames have received much attention in recent years in the US, and other authors have extensively covered the latest research and knowledge on this topic[25,26]. Design requirements for BRB frames will be included in the 2005 Edition of the Seismic Provisions for Structural Steel Buildings, published by the American Institute of Steel Construction, even though at this time, most BRB systems are proprietary (as a result, testing of components and representative sub-assemblies are typically required). Many uniaxial tests of diverse types of BRBs have been conducted to date, consistently exhibiting stable hysteresis behavior (with full hysteresis loops) and excellent low-cycle fatigue life. Limited subassembly test results have show some undesirable failure modes, typically due to buckling and cracking of gusset plates. However, it was observed in those cases that similar failures would have occurred in all types of braced frames pushed to the same displacement histories[27], highlighting the limited knowledge and significant need for further research on the behavior of braced frames (with their surrounding frames) in general.

\section{Steel Plate Shear Walls}

The selection of steel plate shear walls (SPSWs) as the primary lateral force resisting system in buildings has increased in recent years as design engineers discover the benefits of this option. Its use has matured since initial designs, which did not allow for utilization of the post-buckling strength, but only elastic and shear yield plate behaviour. Research conducted by Thorburn et al.[28], Lubell et al.[29], Driver et al.[30], Caccese et al.[31], Berman \& Bruneau[32] (among many) supported the SPSW design philosophy that reduced plate thickness by allowing the occurrence of shear buckling. After buckling, the lateral load is carried in the panel via the subsequently developed diagonal tension field action. Smaller panel thicknesses also reduce forces on adjacent members, resulting in more efficient framing designs. Understanding of the seismic behaviour of thin-plate SPSWs has significantly improved in recent years, and design requirements for SPSWs are scheduled for implementation in the 2005 Edition of the Seismic Provisions for Structural Steel Buildings, published by the American Institute of Steel Construction. Yet, some obstacles still exist that may impede further widespread acceptance of this system. For example, using the yield stress for typically available steel material, the panel thickness as required by a given design situation may often be much thinner than the minimum hot-rolled steel plate thickness typically available from steel mills. In such a case, using the minimum available plate thickness would result in a large difference in panel forces from that required by calculations. Attempts at alleviating this problem have been addressed by the use of light-gauge coldformed steel[33].

Vian \& Bruneau[34] investigated the seismic performance of SPSWs designed and fabricated using low-yield-strength (LYS) steel panels and reduced beam sections (RBS) added to the beam ends in order to force all inelastic action in the beams to those locations (Fig. 8). It was felt that this would promote increasingly efficient designs of the 'anchor beams', defined as the top and bottom beams in a multistory frame, which 'anchor' the tension field forces of the SPSW infill panel.

SPSWs with low-yield steel webs appear to be a viable option for use in resistance of lateral loads imparted during seismic excitation. The lower yield strength and thickness of the tested plates result in a reduced stiffness and earlier onset of energy dissipation by the panel as compared with conventional hot-rolled plate. The perforated panel specimen shows promise towards alleviating stiffness and over-strength concerns using conventional hotrolled plates. This option also provides access for utilities to penetrate the system, important in a retrofit situation, in which building use is predetermined prior to SPSW implementation. The reduced beam section details in the beams performed as designed, as shown in Fig. 9. Use of this detail may result in more economical designs for beams 'anchoring' an SPSW system at the top and bottom of a multi-storey frame. 

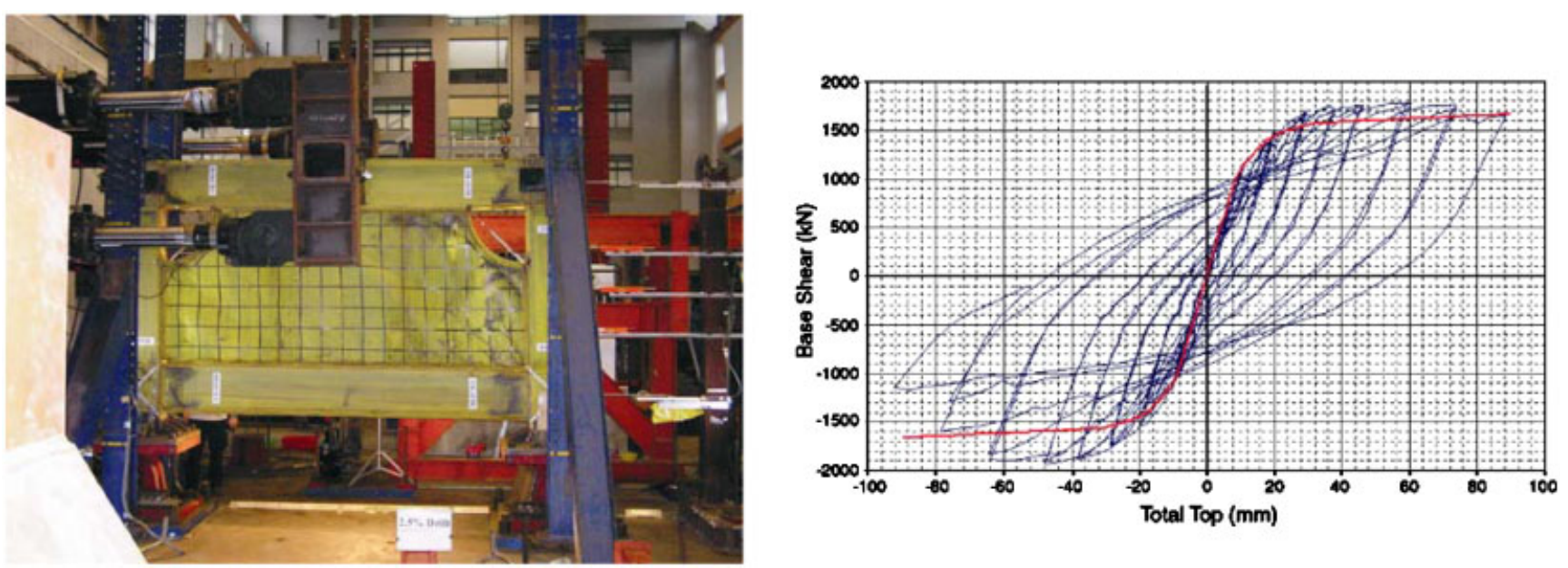

Fig. 8 SPSW specimen with cut-out corners (left) and typical hysteresis loops solid wall specimen[34]

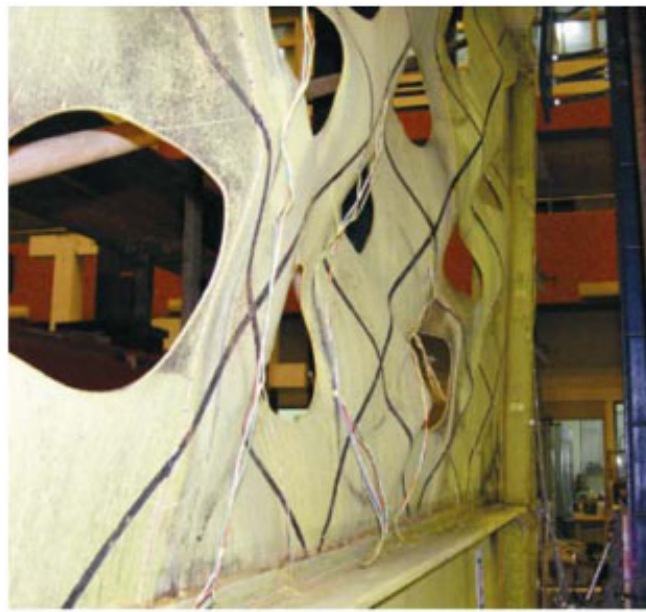

Buckled Panel Following Test

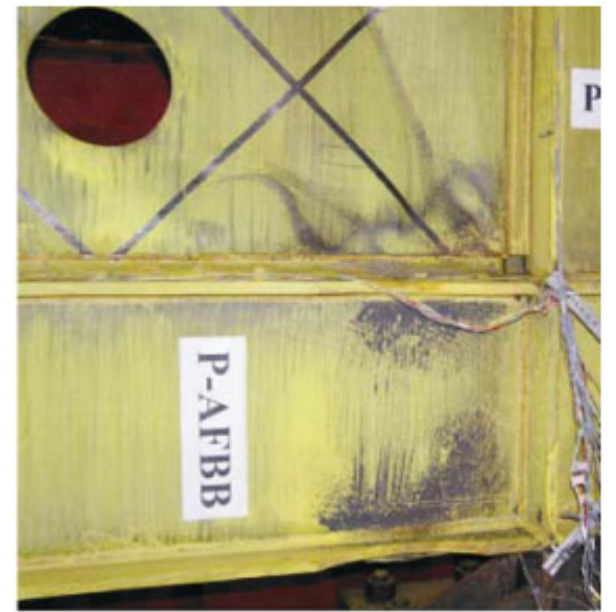

RBS Yielding

Fig. 9 Buckled panel and RBS yielding of SPSW specimen[34].

Ongoing research is focusing on developing reliable models that can capture the experimentally observed behaviour, and investigating the benefits of this system on enhancing the seismic performance of nonstructural components.

\section{Plastic rotation limits}

Lee \& Stojadinovic[35] developed a cyclic yield-line plastic hinge model to estimate the rotation capacity of US-type fully restrained steel moment connections subjected to earthquakes (Fig. 10).

A simplified plastic flow rule is used to model yielding at the yield lines that develop in the beam after local buckling. Two limit states are considered using the cyclic yield-line plastic hinge model. First, post-peak connection strength degradation due to local and lateral-torsional buckling is used to establish a connection rotation limit similar to the limit used in FEMA-350. Second, a low-cycle fatigue crack initiation model based on accumulative local strain concept at the critical yield line is used to predict crack initiation at the creases of the local buckles in the plastic hinge and, thus, limit plastic hinge rotation. The proposed analytical model was used to estimate connection rotation capacities after buckling of the beam. These estimates compare well to the rotation capacities of connections tested within the SAC Joint Venture programme. The intention of further development of the yield-line plastic hinge model is to develop an analytical platform for development of new connection designs without any but the minimum required proof-test experiments.

\section{Recent research for retrofit of bridges}

\section{SHeAR LiNKS}

Dusicka et al.[36,37] investigated built-up shear links constructed from plates of different grades of steel, including high-performance steels (HPS) as well as Japanese low-yield-point steels (LYP). These steels provided a range of nominal yield strengths from $100 \mathrm{MPa}$ ( $14.5 \mathrm{ksi})$ to $485 \mathrm{MPa}$ (70 ksi). The LYP steel in particular allowed for innovative designs of compact shear links without stiffeners. 

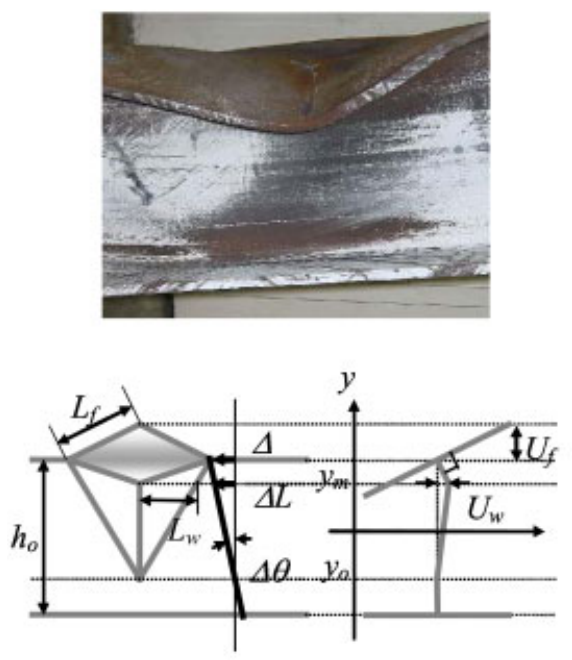

Fig. 10 Yield-line plastic hinge model of local buckling[35]
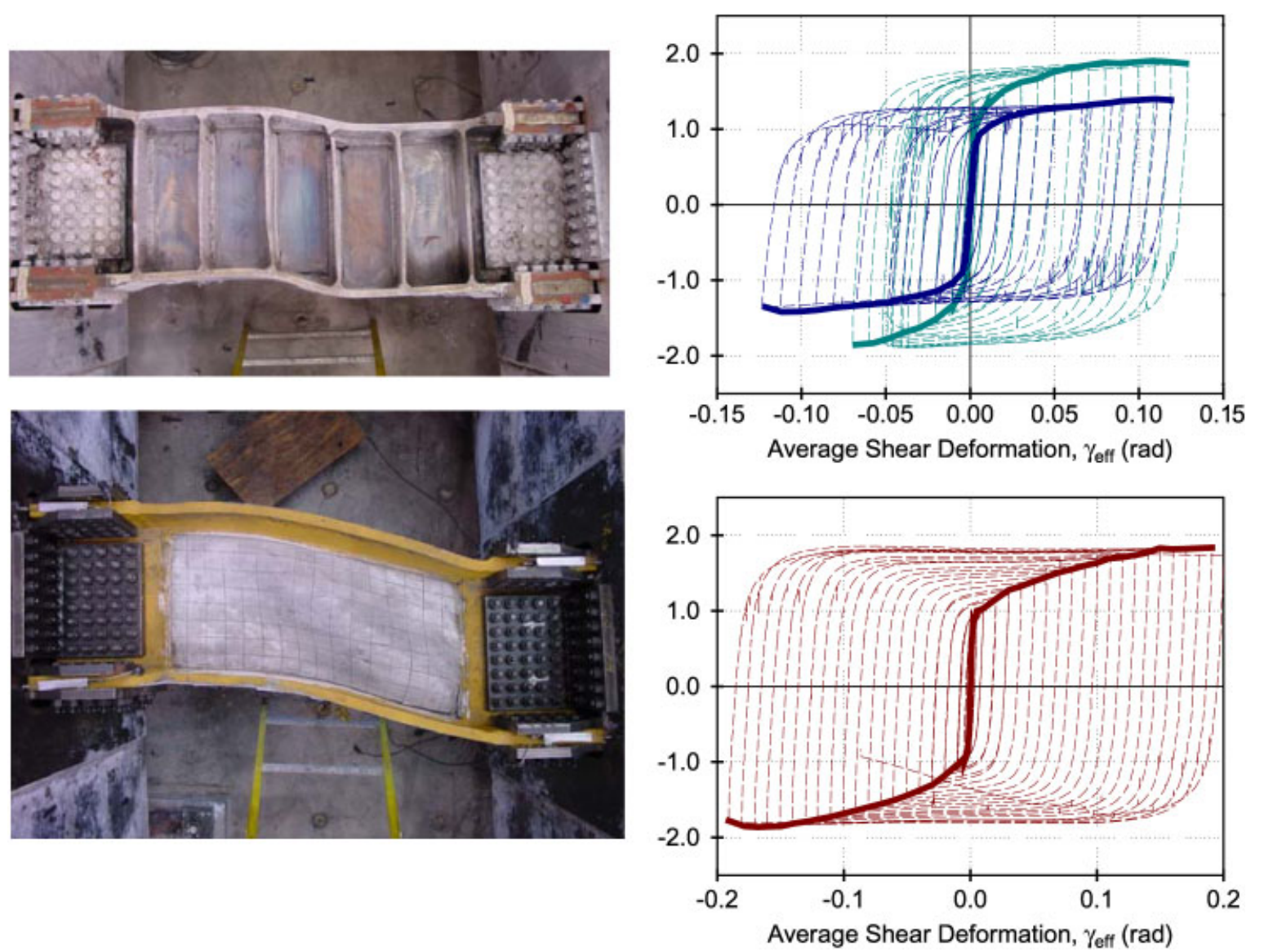

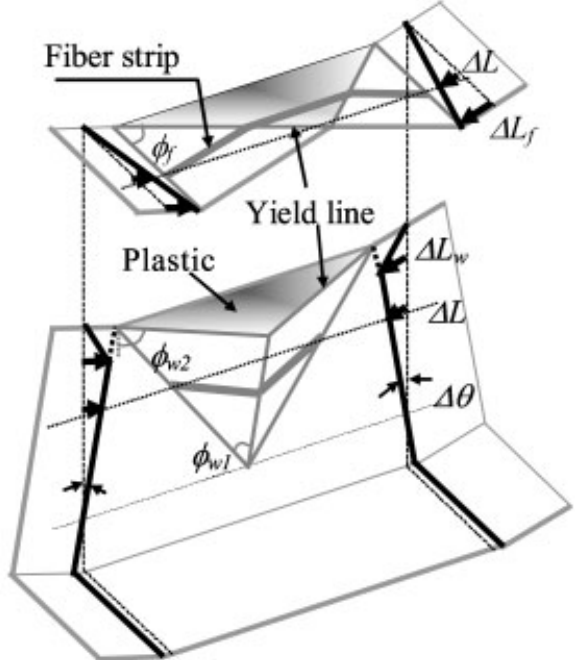

Fig. I I Deformation near end of test cyclic test results for shear links with high performance steel (top) and low-yield steel (bottom)[36]

Cyclic plastic deformations were applied to determine the deformation capacity, maximum resistance and ultimate failure mode of the shear link components (Fig. 11). All links tested exhibited ductile hysteretic behaviour. In links where stiffeners were used, the failure mode initiated with cracks in the web at the stiffener connections and propagated along the heat-affected zone, leading to progressive tearing and failure at $0.12 \mathrm{rad}$ shear rotation. Significant improvement in deformation capacity was found for the LYP links without stiffeners leading to shear deformations up to $0.20 \mathrm{rad}$.The ultimate strength was found to vary significantly among all of the specimens, the results of which directly affects capacity design of the associated structural components.

\section{TruSS PIERS}

Steel truss bridges are found in nearly every region of the US. Many existing steel truss bridges consist of riveted construction with built-up, lattice type 

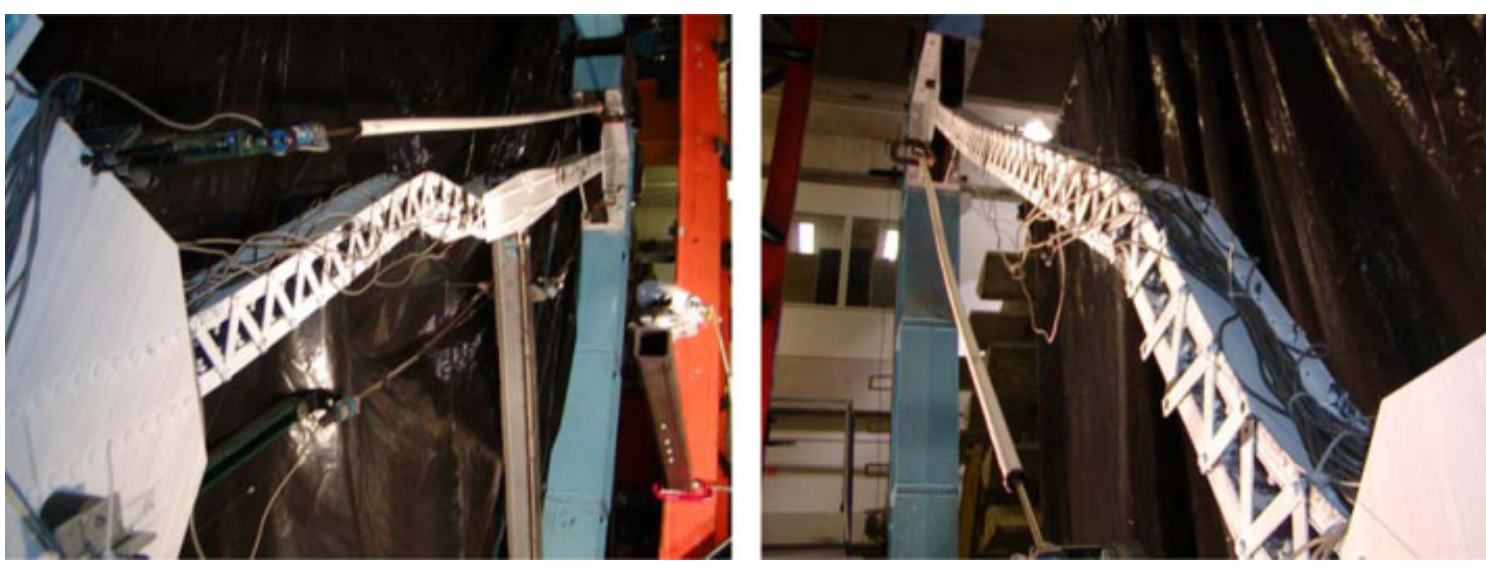

Fig. I Global buckled shape of various specimens[38]

members supporting a slab-on-girder bridge deck. Truss piers are typically in an X-or V-braced configuration. These built-up lattice type members and their connections can be the weak link in the seismic load path. Recent experimental testing (Fig. 12) of these members revealed the limited ductility that can be achieved due to global and local buckling causing significant strength and stiffness degradation[38]. Existing, riveted connections and deck diaphragm bracing members typically possess little on no ductility[39]. Another possible non-ductile failure location is the anchorage connection at the pier-to-foundation interface. Analyses of 'typical' steel-concrete connections suggests it may be unable to resist even moderate seismic demands.

While strengthening these existing vulnerable elements to resist seismic demands elastically is an option, this method can be expensive, and also gives no assurance of performance beyond the elastic limit. Therefore it is desirable to have structures able to deform inelastically, limiting damage to easily replaceable, ductile structural 'fuses' able to produce stable hysteretic behaviour while protecting existing non-ductile elements and preventing residual deformations using a capacity-based design procedure.

Failure of, or releasing of, the anchorage connection allows a steel truss pier to rock on its foundation, partially isolating the pier. Addition of passive energy dissipation devices at the uplifting location can control the rocking response while providing energy dissipation[40]. This system can also be designed to provide an inherent restoring force capability that allows for automatic re-centering of the tower, leaving the bridge with no residual displacements after an earthquake. The device used in this application is the unbonded brace. An unbonded brace is a type of buckling-restrained brace (BRB) and consists of a steel core surrounded by a restraining part, allowing the brace to reach full yield in tension and compression. Experimental testing of the braces can be found in Iwata \& Kato[41]. Also, this strategy limits the retrofit effort by working at a fairly accessible

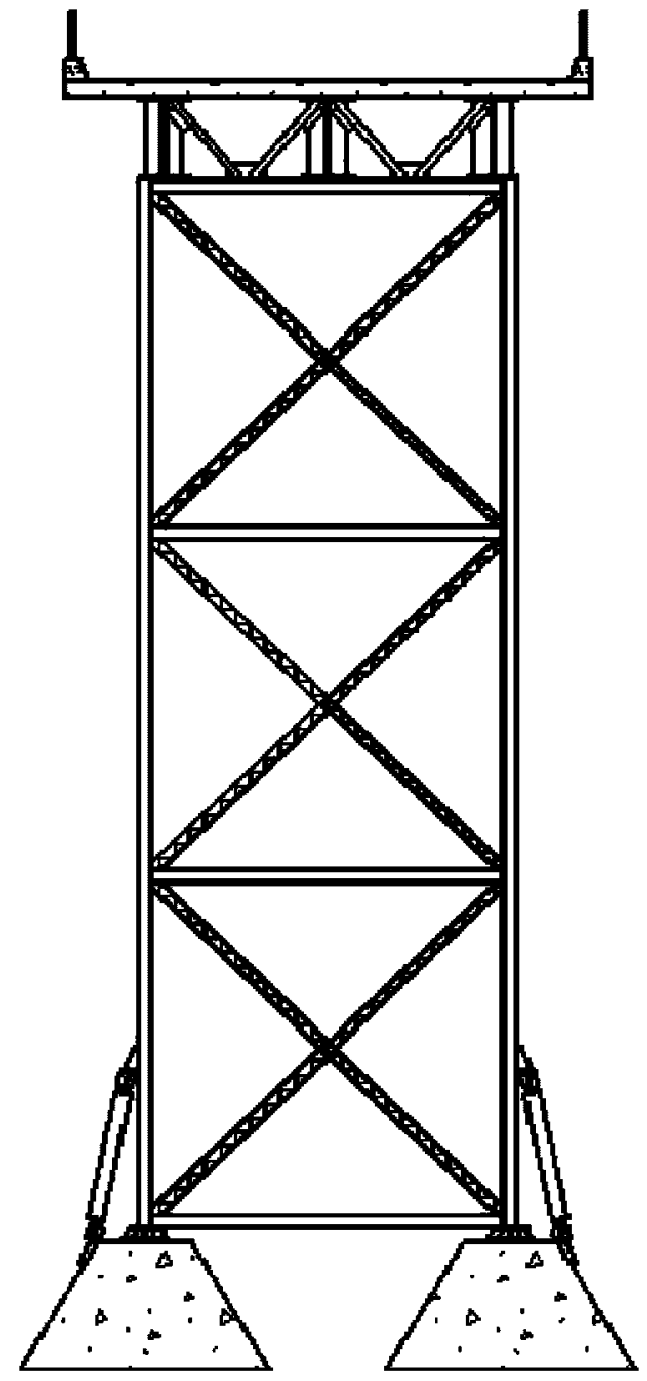

Fig. I3 Sketch of retrofitted pier with unbonded braces[40]

location. A sketch of a retrofitted bridge pier is shown in Fig. 13.

A controlled rocking approach to seismic resistance was implemented into the design of the South Rangitikei Rail Bridge, Mangaweka, New Zealand in 1981[42] and was later used as a seismic retrofit technique in the Lions' Gate Bridge located in 
Vancouver, British Colombia[43] as shown in Fig. 14. Both bridges use steel yielding devices across the anchorage interface for added energy dissipation.

The controlled rocking bridge pier system considered can be shown to develop a flag-shaped hysteresis similar to the self-centering systems described above. This is due to the combination of pure rocking response from the restoring moment provided by the bridge deck weight and energy dissipation provided by yielding of the unbonded braces. Hysteretic behavior in the first and subsequent cycles, for a given magnitude of inelastic deformation in the unbonded braces, is shown on a single plot in Fig. 15.
A parametric study was undertaken in order to provide a preliminary understanding of system behaviour. Results obtained were then used to assist in formulating a design procedure that can reliably predict the system's ultimate seismic response. In the perspective of seismic retrofit, a capacity-based design procedure was also proposed to protect non-ductile elements while limiting energy dissipation to the specially detailed steel yielding devices. In a seismic retrofit perspective, a large number of constraints exist, and a systematic design procedure that satisfies all constraints was developed. The proposed design procedure was complemented by a graphical approach in which the boundaries of compliance and non-compliance of the design constraints are plotted
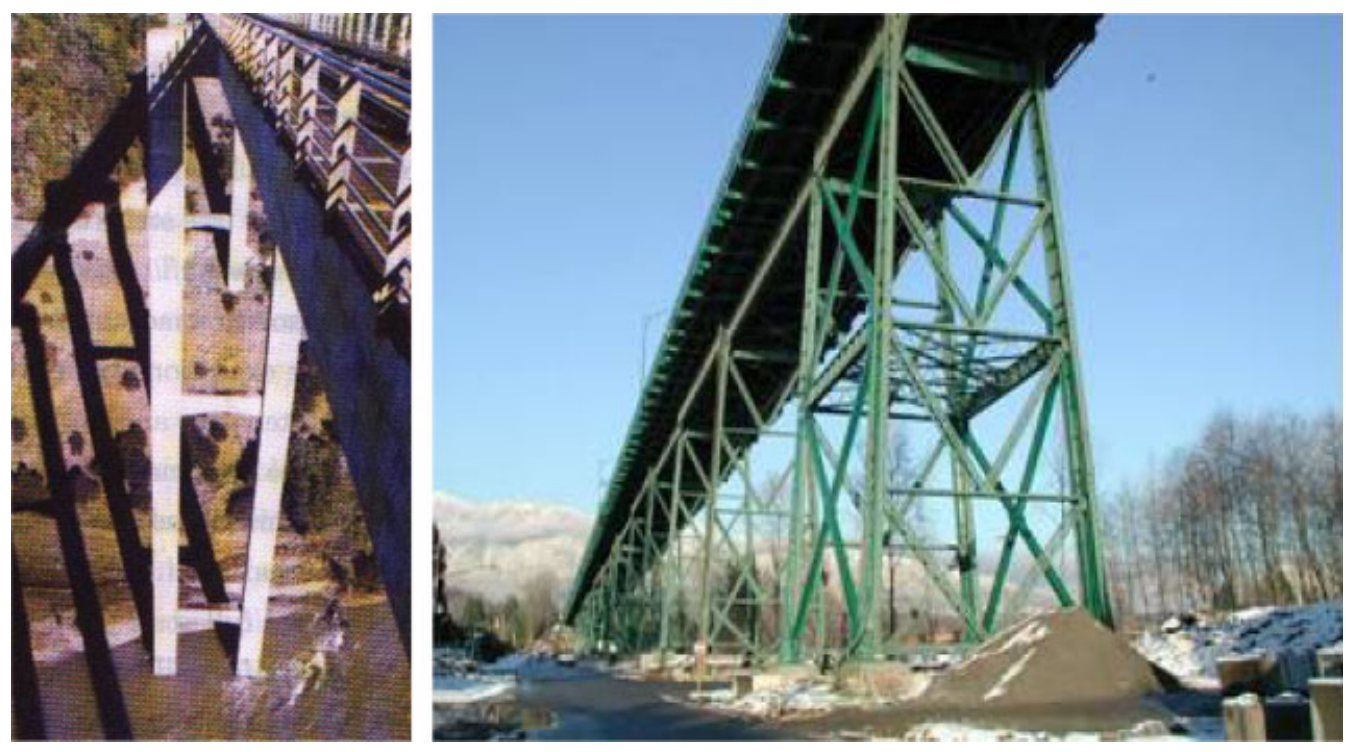

Fig. I4 South Rangitikei Rail Bridge[42] (left) and Lion's Gate Bridge- north approach (personal communication, Hamersley, B., Engineer, Klohn Crippen Transportation Group, 2002) (right)

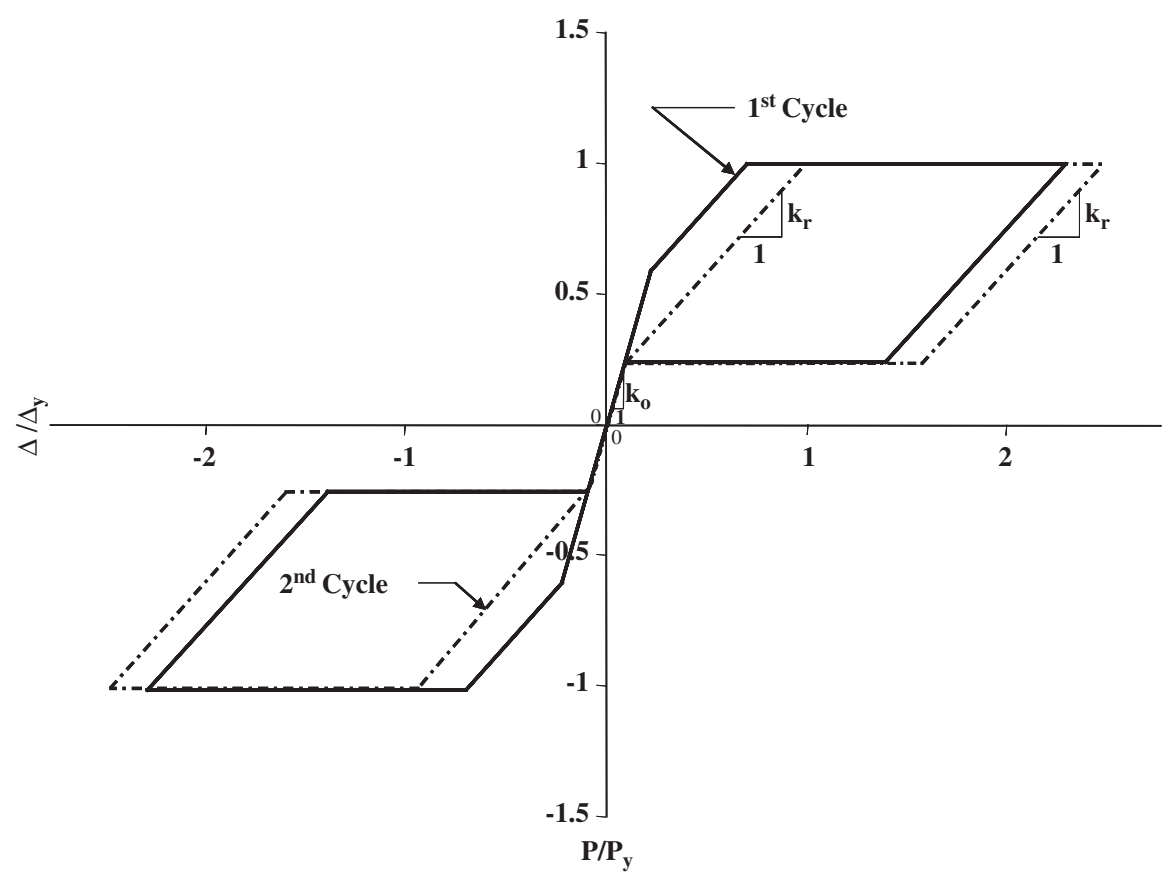

Fig. 15 Hysteretic behavior of rocking truss pier[40] 
with respect to two key design parameters. The two design parameters used are the length and crosssectional area of the unbonded brace, $L_{\mathrm{ub}}$ and $A_{\mathrm{ub}}$ respectively[40].

\section{Conclusions}

This paper has highlighted selected activities currently underway in the US on developing new methods to seismically design or retrofit steel buildings and bridges. This sustained research is generating the knowledge needed to ensure that the highest level of seismic performance expected of these newer systems will be achieved.

\section{Acknowledgements}

The authors thank S. Leelataviwat (Asian University of Science and Technology, Thailand);

C. Christopoulos (University of Toronto); B. Folz (University of British Columbia); J. H. Collins (PCSA Structural Solutions, Seattle WA); M. Garlock R. Sause (Lehigh University); R. J. Dexter, D. Lee, S. C. Cotton, S. D. Prochnow, Y. Ye and C. Tort (University of Minnesota); P. Dusicka and I. G. Buckle (University of Nevada Reno); J. Berman, K. Lee, M. Pollino and D. Vian (University at Buffalo); S. A. Civjan (University of Massachusetts at Amherst), J. L. Gross (NIST); K. Kasai (Tokyo Institute of Technology), C. S. Yang (Georga Tech), N. R. Iwankiw (Hughes and Associates, Chicago) and Dr. Kyungkoo Lee (University of California, Berkeley). Any opinions, findings, conclusions, and recommendations presented in this paper are those of the writer and do not necessarily reflect the views of the sponsors.

\section{References}

[I] FEMA. Recommended seismic design criteria for new steel momentframe buildings. Report No. FEMA-350, Federal Emergency Management Agency: Washington, D.C. 2000.

[2] Uang CM, Yu QS, Noel S \& Gross JL. Cyclic testing of steel moment connections rehabilitated with RBS or welded haunch. Journal of Structural Engineering (ASCE) 2000: 126(I): 57-68.

[3] Yu QS, Uang CM \& Gross JL. Seismic rehabilitation design of steel moment connection with welded haunch. Journal of Structural Engineering (ASCE) 2000: 126(1): 57-68.

[4] Gross JL, Engelhardt MD, Uang CM, Kasai K \& Iwankiw NR. Modification of existing welded steel moment frame connections for seismic resistance. Steel Design Guide Series No. 12, American Institute of Steel Construction, 82 pages. 1999.

[5] Civjan SA, Engelhardt MD \& Gross JL. Slab effects in SMRF retrofit connection tests. Journal of Structural Engineering (ASCE) 200I: 127(3): 230-237.

[6] Civjan SJ, Engelhardt MD \& Gross JL. Experimental program and proposed design method for the retrofit of steel moment connections. Proceedings of the 12th World Conference on Earthquake Engineering, Auckland: New Zealand. 2000.
[7] Civjan S, Engelhardt MD \& Gross JL. Retrofit of pre-northridge moment resisting connections. Journal of Structural Engineering (ASCE) 2000: I26(I): 69-78.

[8] Hajjar JF, Dexter RJ, Sara DO, Ye Y \& Cotton SC. Continuity plate detailing for steel moment-resisting connections. Engineering Journal (AISC) 2003: 40(4): 89-211.

[9] Prochnow SD, Dexter RJ, Hajjar JF, Ye Y \& Cotton SC. Local flange bending and local web yielding limit states in steel moment-resisting connections. Report No. ST-00-4, Department of Civil Engineering, University of Minnesota: Minneapolis, Minnesota. 2000.

[ 10$]$ Lee D, Cotton SC, Dexter RJ, Hajjar JF, Ye Y \& Ojard SD. Column stiffener detailing and panel zone behavior of steel moment frame connections. Report No. ST-0I-3.2, June, Department of Civil Engineering, University of Minnesota: Minneapolis, Minnesota. 2002.

[I I] Ye Y, Hajjar JF, Dexter RD, Prochnow SC \& Cotton SC. Nonlinear analysis of continuity plate and doubler plate details in steel moment frame connections. Report No. ST-00-3, Department of Civil Engineering, University of Minnesota: Minneapolis, Minnesota. 2000.

[12] Lee D, Cotton SC, Hajjar JF, Dexter RJ \& Ye Y. Cyclic behavior of steel moment-resisting connections reinforced by alternative column stiffener details: I. Connection performance and continuity plate detailing. II. Panel zone behavior and doubler plate detailing. Engineering Journal, AISC 2005. (in press).

[13] Tort C \& Hajjar JF. Damage assessment of rectangular concrete-filled steel tubes for performance-based design. Earthquake Spectra 2004: 20(4): 1317-1348.

[14] Leelataviwat S, Goel SC \& Stojadinovic B. Drift and yield mechanism based seismic design and upgrading of steel moment frames. Research Report No. UMCEE 98-29, Department of Civil \& Environmental Engineering, The University of Michigan: Ann Arbor, MI, August. 1998.

[15] Christopoulos C, Filiatrault A \& Uang C-M. Self-Centering PostTensioned Energy Dissipating (PTED) Steel Frames for Seismic Regions. Structural Systems Research Project Report No. SSRP-2002/06, Department of Structural Engineering, University of California: San Diego, La Jolla, CA, 2002a. p 292.

[16] Christopoulos C, Filiatrault A, Folz B \& Uang C-M. Post-tensioned energy dissipating connections for moment-resisting steel frames. Journal of Structural Engineering (ASCE) 2002b: |28(9): I। II-I| 20.

[17] Collins JH \& Filiatrault A. Application of post-tensioned energy dissipating (PTED) connections in steel moment-resisting frames. Report No. SSRP2003/05, Department of Structural Engineering, University of California: San Diego. 2004.

[18] Garlock M, Ricles JM, Sause R \& Lu LW. Seismic analysis and testing of post-tensioned steel moment connections for MRF systems. Proceedings-Frames with Partially Restrained Connections, NSF Sponsored Workshop: Atlanta, GA, September. 1998.

[19] Garlock M, Ricles JM \& Sause R. Experimental studies on full-scale post-tensioned steel moment connections. 13th World Conference on Earthquake Engineering, Vancouver, B.C., Canada, Paper No. 25/4, 2004.

[20] Ricles JM, Sause R, Garlock M \& Zhao C. Post-tensioned seismic resistant connections for steel frames. Journal of Structural Engineering (ASCE) 200I: 127(2): ||3-12|.

[2I] Ricles JM, Sause R, Peng SW \& Lu LW. Experimental evaluation of earthquake resistant post-tensioned steel connections. Journal of Structural Engineering (ASCE) 2002: 128(7): 850-859.

[22] Leon RT \& Yang CS. Special inverted-V-braced frames with suspended zipper struts. Georgia Institute of Technology, December I, 2003.

[23] Khatib IF, Mahin SA \& Pister KS. Seismic behavior of concentrically braced steel frames. Report No. UCB/EERC-88/01. Berkeley: Earthquake Engineering Research Center. University of California. 1988.

[24] Tremblay R \& Tirca L. Behavior and design of multi-story zipper concentrically braced steel frames for the mitigation of soft-story response, 2003.

[25] Sabelli R, Mahin SA \& Chang C. Seismic demands on steel bracedframe buildings with buckling-restrained braces. Engineering Structures 2003: 25: 655-666.

[26] Uang CM \& Nakashima M. Steel buckling-restrained braced frames. Chapter 16 in Earthquake Engineering: Recent Advances and Applications, CRC Press: Boca Raton, FL. 2003.

[27] López WA, Gwie DS, Saunders M \& Lauck TW. Lessons learned from large-scale tests of unbonded braced frame subassemblage. Proceedings 7/st Annual Convention of SEAOC, Sacramento, CA, 2002. Pp. $171-183$. 
[28] Thorburn LJ, Kulak GL \& Montgomery CJ. Analysis of steel plate shear walls. Structural Engineering Rep. No. 107, Dept. of Civil Engineering, University of Alberta: Edmonton, Alberta, Canada. 1983.

[29] Lubell AS, Prion HGL, Ventura CE \& Rezai M. Unstiffened steel plate shear wall performance under cyclic loading. Journal Structural Engineering 2000 453-460.

[30] Driver RG, Kulak GL, Kennedy DJL \& Elwi AE. Seismic behavior of steel plate shear walls. Structural Engineering Report No. 215 Department of Civil Engineering, University of Alberta: Edmonton, Alberta, Canada. 1997.

[3 I] Caccese V, Elgaaly M \& Chen R. Experimental study of thin steel-plate shear walls under cyclic load. Journal Structural Engineering 1993: 573-587.

[32] Berman JW \& Bruneau M. Steel plate shear walls are not plate girders. Engineering Journal (AISC) 2004: 4I(3): 95-106.

[33] Berman JW \& Bruneau M. Experimental investigation of light-gauge steel plate shear walls for the seismic retrofit of buildings. Technical Report MCEER-03 000 I, Multidisciplinary Center for Earthquake Engineering Research, State University of New York at Buffalo: Buffalo, N.Y. 2003.

[34] Vian D \& Bruneau M. Testing of special LYS steel plate shear walls. 13th World Conference on Earthquake Engineering, Paper No. 978 2004. Vancouver, Canada.

[35] Lee K \& Stojadinovic B. Low-cycle fatigue limit on seismic rotation capacity for us steel moment connections. Proceedings of the 13th World Conference on Earthquake Engineering, Paper No. 90 Vancouver, B.C., Canada, 2004.

[36] Dusicka P, Itani AM \& Buckle IG. Evaluation of conventional and specialty steels in shear link hysteretic energy dissipators. 13th World Conference on Earthquake Engineering, Paper No. 522, Vancouver, B.C., Canada. 2004

\section{Michel Bruneau}

Director, Multidisciplinary Center for Earthquake Engineering Research, and Professor, Department of Civil, Structural, and Environmental Engineering, 105 Red Jacket Quadrangle, University at Buffalo,

Buffalo, NY, USA

E-mail: Bruneau@mceermail.buffalo.edu

\section{Michael Engelhardt}

Professor, University of Texas Austin,

Department of Civil Engineering,

Austin, TX, USA

E-mail: mde@mail.utexas.edu

\section{Andre Filiatrault}

Deputy Director, Multidisciplinary Center for Earthquake Engineering Research, and Professor, Department of Civil, Structural, and Environmental Engineering, 109 Red Jacket Quadrangle, University at Buffalo,

Buffalo, NY, USA

E-mail: filiatrault@mceermail.buffalo.edu

\section{S C Goel}

Professor, University of Michigan,

Department of Civil Engineering,

Ann Arbor, MI, USA

E-mail: Subhash@engin.umich.edu

\section{Ahmad Itani}

Associate Professor , University of Nevada Reno,

Department of Civil Engineering, 258,

Center for Civil Engineering Earthquake Research,

Reno, NV, USA

E-mail: itani@unr.edu
[37] Dusicka P, Itani AM \& Buckle IG. Cyclic behavior of shear links and tower shaft assembly of San Francisco-Oakland bay bridge tower. Report No. CCEER 02-06, Center for Civil Engineering Earthquake Research, University of Nevada: Reno, NV. 2002.

[38] Lee K \& Bruneau M. Seismic vulnerability evaluation of axially loaded steel built-up laced members. Technical Report MCEER-04-0007, Multidisciplinary Center for Earthquake Engineering Research, State University of New York at Buffalo: Buffalo, NY. 2004.

[39] Ritchie P, Kauh N \& Kulicki J. Critical seismic issues for existing steel bridges. Technical Report MCEER-99-0013, Multidisciplinary Center for Earthquake Engineering Research, State University of New York at Buffalo: Buffalo, NY. 1999.

[40] Pollino M \& Bruneau M. Seismic retrofit of bridge steel truss piers using a controlled rocking approach. Report No. MCEER-04-00 I , Multidisciplinary Center for Earthquake Engineering Research, University at Buffalo, 2004.

[4I] Iwata M, Kato T \& Wada A. Buckling-restrained braces as hysteretic dampers behaviour of steel structures in seismic areas. STESSA 2000, 2000 : 33-38.

[42] Priestley MJN, Seible F \& Calvi GM. Seismic design and retrofit of bridges. John Wiley \& Sons: New York. 1996.

[43] Dowdell D \& Hamersley B. Lions' gate bridge north approach: Seismic retrofit, behaviour steel structures in seismic areas: Proceedings of the $3 \mathrm{rd}$ International Conference: STESSA 2000; Montreal, Canada, August 2I-24, 2000, 200I: 319-326.

\section{Jerome Hajjar}

Professor, University of Minnesota, Department of Civil Engineering, 500 Pillsbury Dr., SE, Minneapolis, MN, USA E-mail: hajjar@struc.ce.umn.edu

\section{Roberto Leon}

Professor, Georgia Institute of Technology, School of Civil and Environmental Engineering, 790 Atlantic Ave., Atlanta, GA, USA

E-mail: rleon@ce.gatech.edu

\section{James Ricles}

Bruce G. Johnston Professor of Structural Engineering, Lehigh University,

II7 ATLSS Drive, H BIdg., Bethlehem, PA, USA

E-mail: jmr5@lehigh.edu

\section{Bozidar Stojadinovic}

Associate Professor, University of California Berkeley,

Department of Civil and Environmental Engineering,

72I David Hall, \#1710, Berkeley, CA, USA

E-mail: boza@ce.berkeley.edu

\section{Chia-Ming Uang}

Professor, University of California San Diego,

Department of Structural Engineering, 409 University Center, La Jolla, CA, USA

E-mail: cmu@ucsd.edu 